\title{
Analisis Berpikir Kreatif Siswa dalam Menyelesaikan Masalah SPLDV ditinjau dari Kemampuan Matematika
}

\author{
Masita Ulil Syahara1, Erna Puji Astutik ${ }^{2 *}$ \\ 1,2*Pendidikan Matematika, Universitas PGRI Adi Buana Surabaya \\ Jalan Dukuh Menanggal XII, Kec. Gayungan, Kota SBY, Jawa Timur, Indonesia \\ 1mashita.ulil@gmail.com; 2*erna_pa@unipasby.ac.id
}

Artikel diterima: 23-11-2020, direvisi: 26-05-2021, diterbitkan: 31-05-2021

\begin{abstract}
Abstrak
Kreativitas sangat dibutuhkan untuk menyelesaikan masalah sehingga kemampuan berfikir kreatif sangat penting untuk dimiliki oleh siswa. Tujuan penelitian ini adalah untuk mendeskripsikan tingkat berpikir kreatif siswa yang didasarkan pada kemampuan matematika tinggi, sedang, dan rendah dalam menyelesaikan masalah matematika. Pendekatan pada penelitian ini ialah deskriptif kualitatif. Subyek dalam penelitian ini yaitu tiga siswa kelas VIII SMP di Surabaya yang masing-masing terdiri dari siswa berkemampuan matematika tinggi, sedang, dan rendah. Pengumpulan data dilakukan dengan teknik tes dan wawancara. Teknik analisis data meliputi tahapan reduksi data, penyajian data, dan penarikan kesimpulan yang didasarkan pada tiga indikator berpikir kreatif yaitu kefasihan, fleksibilitas, dan kebaruan. Hasil penelitian menunjukkan bahwa siswa berkemampuan matematika tinggi memenuhi tiga indikator berpikir kreatif sehingga memiliki tingkat kemampuan berpikir kreatif 4 (sangat kreatif). Siswa berkemampuan matematika sedang memenuhi dua indikator berpikir kreatif yaitu kefasihan (fluency) dan fleksibilitas (flexibility) sehingga memiliki tingkat kemampuan berpikir kreatif 3 (kreatif). Adapun siswa berkemampuan matematika rendah tidak memenuhi tiga indikator berpikir kreatif sehingga memiliki tingkat kemampuan berpikir kreatif 0 (tidak kreatif). Hasil tersebut menunjukkan bahwa kemampuan berfikir kreatif siswa ditentukan oleh kemampuan matematika siswa.

Kata Kunci: Berpikir Kreatif, Kemampuan Matematika, SPLDV.
\end{abstract}

\section{Profile of Students' Creative Thinking in Solving 'Two Variables Linear Equation Systems' Problems Based on Mathematical Ability}

\section{Abstract}

Creativity is needed to solve problems so that the ability to think creatively is very important for students to have. The purpose of this study was to describe the level of creative thinking of students based on high, medium, and low mathematical abilities. The approach of this research was descriptive qualitative. The subjects in this study were three students of class VIII SMP in Surabaya, each consisting of students with high, medium, and low math abilities. Data collection was carried out by test and interview techniques. The data analysis techniques used include the stages of data reduction, data presentation, and drawing conclusions based on three indicators of creative thinking, namely fluency, flexibility, and novelty. The results of the study, it shows that students with high mathematical abilities meet the three indicators of creative thinking so that they have a creative thinking ability level of 4 (very creative). Students with medium mathematical abilities are meeting two indicators of creative thinking, namely fluency and flexibility so that they have a creative thinking ability level 3 (creative). Students with low mathematical abilities do not meet the three indicators of creative thinking so they have a creative thinking ability level of 0 (not creative). These results indicate that students 'creative thinking abilities are determined by students' mathematical abilities.

Keywords: Creative Thinking, Mathematical Ability, Two Variables Linear Equation Systems. 


\section{Pendahuluan}

Pendidikan merupakan usaha sadar untuk mewujudkan suasana pembelajaran yang dapat menumbuhkan keaktifan siswa untuk mengembangkan potensi dirinya (Undang-Undang Republik Indonesia Nomor 20 Tahun 2003 tentang Sistem Pendidikan Nasional). Salah satu tujuan pendidikan adalah membentuk siswa peserta didik yang kreatif (Sujana, 2019; Dwiputri \& Anggraeini, 2021). Hal tersebut sesuai dengan Peraturan Pemerintah Nomor 17 Tahun 2010. Selain itu, tujuan pendidikan pada kurikulum 2013 sebagaimana yang tertuang dalam Peraturan Menteri Pendidikan dan Kebudayaan Republik Indonesia Nomor 69 Tahun 2013 yaitu mempersiapkan peserta didik agar memiliki kemampuan sebagai individu yang kreatif. Terlihat kemampuan yang ingin dicapai pada kedua tujuan pendidikan di atas ialah kemampuan berpikir kreatif. Oleh sebab itu, kemampuan berfikir kreatif sangat penting untuk dimiliki oleh siswa (Zubaidah, Fuad, Mahanal, \& Suarsini, 2017; Fitriani \& Yarmayani, 2018).

Mata pelajaran yang sangat penting di sekolah ialah matematika (Markovits \& Forgasz, 2017; Akbayir, 2019; Sari \& Afriansyah, 2020). Matematika tidak hanya memberikan kemampuan kuantitatif saja, melainkan memberikan proses berpikir terutama dalam berpikir HOTS seperti menganalisis, mengevaluasi, dan mencipta hingga memiliki kemampuan problem solving (Sofyan, 2019; Rafiqoh, 2020). Aktivitas dalam pembelajaran matematika tersebut sangat identik dengan kegiatan berpikir, dimana matematika digunakan sebagai alat untuk menyelesaikan permasalahan yang memerlukan logika berpikir (Uno dalam Ayuni, Firmansyah, Senjayawati, \& Maya, 2018). Selain itu, matematika juga menekankan pada kriteria berpikir kreatif siswa. Hal tersebut sejalan dengan Marchis (dalam Huriyah, 2017:50) bahwa komponen penting dari kompetensi pemecahan masalah matematika ialah mampu berpikir secara kreatif dan kritis, yang berarti berpikir dapat membantu menyelesaikan masalah, dan banyaknya masalah membutuhkan penyelesaian yang baru bagi sekelompok orang dan sebaliknya pemecahan masalah dapat menghasilkan sesuatu yang tidak biasa.

Menurut Johnson dan Rising (dalam Amala \& Ekawati, 2016:302), pada dasarnya pembelajaran di dalam kelas sangat memerlukan pemecahan masalah matematika. Berikut alasan yang mendasarinya, adalah: (1) pemecahan masalah adalah suatu proses seseorang mempelajari konsep-konsep baru; (2) pemecahan masalah dapat berupa langkahlangkah untuk melatih keterampilan komputasi atau perhitungan; (3) melalui pemecahan masalah, seseorang belatih mentransfer konsep serta keterampilan dalam situasi yang modern; (4) pemecahan masalah adalah alat untuk menstimulasi keingintahuan seseorang; dan (5) pengetahuan baru dapat ditemukan melalui pemecahan masalah. Pemecahan masalah matematika biasanya menggunakan prosedur penyelesaian rutin (Saygılı, 2017; Parrot \& Leong, 2018), akan tetapi hal ini dapat mengakibatkan siswa cenderung tidak kreatif dalam menyelesaikan masalah matematika. Hal tersebut sesuai dengan pendapat Yusmanida (dalam Mulyaningsih \& Ratu, 
2018:65) bahwa prosedur penyelesaian rutin yang diajarkan guru kepada siswa mengakibatkan siswa tidak kreatif dalam memecahkan masalah matematika akibatnya siswa tidak bisa memberikan alternatif jawaban yang berbeda-beda pada soal matematika.

Usaha yang mendasar untuk bisa mengembangkan kemampuan berpikir kreatif dalam pembelajaran matematika ialah dengan pemecahan masalah (Apino \& Retnawati, 2017; Nurhikmayati \& Sunendar, 2020). Guru tidak hanya menjelaskan teori dan rumus matematika saja, melainkan siswa diajak untuk memecahkan masalah utamanya yang berhubungan dengan dunia nyata sehingga pemahaman siswa terhadap suatu konsep akan lebih bermakna (Siswono dalam Putri \& Ratu, 2018:103). Pengetahuan matematika yang baik dapat meningkatkan siswa dalam berpikir kreatif (Faturohman \& Afriansyah, 2020). Berpikir kreatif merupakan suatu kebiasaan dari pikiran yang terlatih dengan memperhatikan intuisi, menghidupkan imajinasi, mengungkapkan kemungkinankemungkinan baru, membuat sudut pandang yang menarik dan membangkitkan ide-ide yang tak terduga (Usman dalam Putri \& Ratu, 2018:103).

Berpikir kreatif dalam memecahkan masalah matematika meliputi tiga aspek (Fitriyani \& Yarmayani, 2018) yaitu fluency mengacu pada keberagaman jawaban yang mampu diberika oleh siswa, flexibility mengacu pada kemampuan siswa saat menyelesaikan masalah tidak hanya satu cara tetapi juga dapat memberikan cara lain, dan novelty mengacu pada kebaruan yang ditemukan oleh siswa ketika memecahkan masalah (Siswono dalam Putri \& Ratu, 2018).

Siswono (2018:40) menyebutkan kriteria pada tingkat kemampuan berpikir kreatif siswa didasarkan pada produk berpikir kreatif yang meliputi aspek fluency, flexibility, dan novelty. Adapun kriteria kemampuan berpikir kreatif siswa dapat dilihat pada Tabel 1 berikut.

Tabel 1.

Kriteria Kemampuan Berpikir Kreatif

\begin{tabular}{|c|c|}
\hline Kriteria & Ciri - Ciri \\
\hline $\begin{array}{r}\text { Kriteria } 4 \\
\text { (Sangat } \\
\text { Kreatif) }\end{array}$ & $\begin{array}{l}\text { Peserta didik mampu } \\
\text { menunjukkan fluency, } \\
\text { flexibility, dan novelty dalam } \\
\text { memecahkan maupun } \\
\text { mengajukan masalah. }\end{array}$ \\
\hline $\begin{array}{l}\text { Kriteria } 3 \\
\text { (Kreatif) }\end{array}$ & $\begin{array}{l}\text { Peserta didik mampu } \\
\text { menunjukkan fluency, dan } \\
\text { novelty atau fluency dan } \\
\text { flexibility dalam } \\
\text { memecahkan maupun } \\
\text { mengajukan masalah. }\end{array}$ \\
\hline $\begin{array}{c}\text { Kriteria } 2 \\
\text { (Cukup Kreatif) }\end{array}$ & $\begin{array}{l}\text { Peserta didik mampu } \\
\text { menunjukkan novelty atau } \\
\text { flexibility dalam } \\
\text { memecahkan maupun } \\
\text { mengajukan masalah. }\end{array}$ \\
\hline $\begin{array}{c}\text { Kriteria } 1 \\
\text { (Kurang Kreatif) }\end{array}$ & $\begin{array}{l}\text { Peserta didik mampu } \\
\text { menunjukkan fluency, dalam } \\
\text { memecahkan maupun } \\
\text { mengajukan masalah. }\end{array}$ \\
\hline $\begin{array}{c}\text { Kriteria } 0 \\
\text { (Tidak Kreatif) }\end{array}$ & $\begin{array}{l}\text { Peserta didik tidak mampu } \\
\text { menujukkan ketiga aspek } \\
\text { indikator berpikir kreatif. }\end{array}$ \\
\hline
\end{tabular}

Setiap kemampuan berpikir siswa bermacam-macam, salah satunya diakibatkan oleh kemampuan matematika (Widodo \& Ikhwanudin, 2018). Hal tersebut sesuai dengan penelitian Mufidah (2014) yang menyatakan kemampuan matematika dapat mempengaruhi bepikir kreatif seseorang dalam menyelesaikan masalah matematika. Semakin tinggi kemampuan matematika siswa maka semakin tinggi 
pemikiran dalam merencanakan

penyelesaian dengan baik dan hati-hati serta siswa yang berkemampuan tinggi cenderung sangat kreatif (Tohir \& Abidin, 2018. Berbeda dengan siswa berkemampuan matematika sedang, siswa dapat memecahkan masalah matematika dengan tepat tetapi tidak mampu menunjukkan cara penyelesaian yang berbeda-beda sehingga siswa berkemampuan matematika sedang cenderung kreatif. Sedangkan siswa yang mempunyai kemampuan matematika rendah, hanya bisa menyelesaikan masalah matematika tetapi hasil dari penyelesaian tersebut tidak maksimal dan tidak mampu memberikan alternatif jawaban yang berbeda, sehingga siswa berkemampuan matematika rendah cenderung kurang kreatif.

Salah satu materi dalam pembelajaran matematika yang memerlukan kemampuan berpikir kreatif dalam pemecahannya adalah Sistem Persamaan Linier Dua Variabel (SPLDV). Hal tersebut dikarenakan materi SPLDV sangat relevan dengan permasalahan kehidupan sehari-hari dan memerlukan cara pemecahan masalah yang beragam (Wulandari, Sujadi, \& Aryuna, 2016; Rasnawati, Rahmawati, Akbar, \& Putra, 2019).

Berdasarkan uraian latar belakang di atas, penelitian ini difokuskan pada profil berpikir kreatif siswa dalam menyelesaikan masalah SPLDV ditinjau dari kemampuan matematika. Adapun tujuan dari penelitian ini adalah untuk mendeskripsikan tingkat berpikir kreatif siswa dengan kemampuan matematika tinggi, sedang, dan rendah dalam menyelesaikan masalah SPLDV.

\section{Metode}

Penelitian ini menggunakan pendekatan kualitatif (Sugiyono, 2017; Fahrudi, Maharani, \& Fauzi, 2021). Penelitian ini dilaksanakan di kelas VIII SMP di Surabaya tahun ajaran 2019/2020. Pemilihan subyek menggunakan teknik purposive sampling yaitu peneliti memilih tiga siswa dengan masing-masing siswa memiliki kategori kemampuan matematika tinggi, sedang, dan rendah (Ardhiyanti, Sutriyono, \& Pratama, 2019).

Teknik pengumpulan data dalam penelitian ini melalui metode Tes dan Wawancara yang dijelaskan sebagai berikut:

1. Tes Kemampuan Matematika (TKM)

Tes Kemampuan Matematika (TKM) digunakan peneliti untuk memilih 3 subyek dengan kemampuan matematika tinggi, sedang dan rendah. TKM dilaksanakan pada awal penelitian yaitu pada tanggal 4 November 2019. Adapun instrumen yang digunakan berupa lembar soal TKM yang terdiri atas 5 soal essay sebagaimana Gambar 1 berikut.

\footnotetext{
Kerjakan soal-soal dibawah ini dengan benar!

1. Suku keberapakah bilangan 69 dari barisan aritmetika $4,9,14,19, \ldots ?$

2. $\mathrm{ABCD}$ adalah jajar genjang jika $\mathrm{A}(1,3), \mathrm{B}(7,3)$, dan $\mathrm{C}(3,6)$. Tentukan luas ABCD tersebut!

3. Suatu fungsi linier didefinisikan dengan $f(x)=\mathrm{a} x-\mathrm{b}$ dengan $x \in$ R. Jika pada fungsi tersebut diketahui $f(1)=3$ dan $f(2)=5$. Tentukan nilai a dan b !

4. Tentukan persamaan garis yang melalui titik $A(2,6)$ dan $\mathrm{B}(4,-3)$ !

5. Tentukan persamaan garis yang melalui titik $A(4,-12)$ dan tegak lurus terhadap garis $\mathrm{y}=\frac{1}{3} \mathrm{x}+2$ !
} Gambar 1. Bentuk Soal TKM

2. Tes Berpikir Kreatif Matematika (TBKM)

Tes Berpikir Kreatif Matematika (TBKM) diberikan kepada tiga subyek penelitian terpilih dengan materi Sistem Persamaan 
Linier Dua Variabel (SPLDV). Tes ini dilaksanakan pada tanggal 21 Desember 2019 dimana hasil tes tersebut digunakan untuk mendapatkan gambaran kemampuan berpikir kreatif siswa dalam memecahkan masalah matematika. Soal tes yang diberikan di sini merupakan bentuk soal terbuka yang terdiri atas dua soal sebagaimana Gambar 2 berikut.

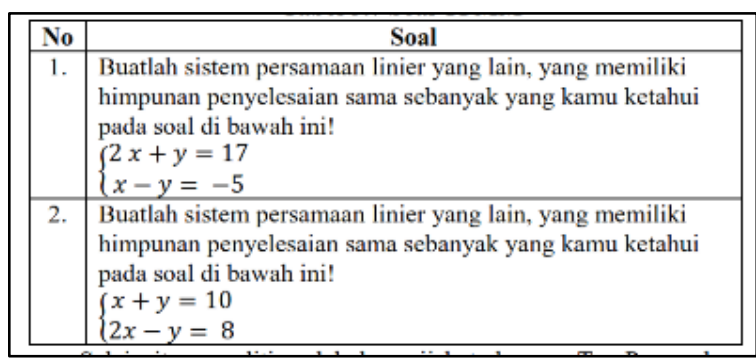

Gambar 2. Bentuk Soal TBKM

\section{Wawancara}

Selain TKM dan TBKM, peneliti juga melakukan wawancara terhadap tiga subjek penelitian. Tes wawancara digunakan untuk mengetahui kejelasan jawaban dalam TBKM dan untuk konfirmasi keabsahan data yang diperoleh dari TBKM. Wawancara dilakukan setelah TBKM pada hari yang sama dengan menggunakan pedoman wawancara semi-terstruktur.

Teknik analisis data pada penelitian ini didasarkan pada analisis data deskriptif kualitatif Menurut Milles dan Huberman (dalam Sugiyono, 2017:338) yang melalui tiga tahapan yaitu reduksi data, penyajian data dan penarikan kesimpulan. Kemudian untuk mengetahui keabsahan data dalam penelitian. Peneliti menggunakan triangulasi teknik yakni menganalisis data berdasarkan hasil Tes Pemecahan Masalah Matematika (TPMM) dan wawancara.

\section{Hasil dan Pembahasan}

Berdasarkan hasil Tes Kemampuan Matematika (TKM) yang diberikan peneliti pada seluruh siswa SMPN 22 Surabaya kelas VIII-C yang berjumlah 37 siswa, perolehan hasil tes TKM siswa tersebut dikelompokan kedalam tiga kategori kemampuan matematika. Terdapat 16 siswa dengan kemampuan matematika tinggi, 17 siswa dengan kemampuan matematika sedang, dan 4 siswa dengan kemampuan matematika rendah.

Akan tetapi, penelitian ini hanya memilih satu subyek pada tiap-tiap kategori untuk dilakukan penelitian secara mendalam. Adapun alasan peneliti dalam memilih tiga siswa tersebut ialah siswa mudah berkomunikasi baik lisan maupun tulisan serta dapat diajak bekerjasama selama penelitian dengan baik serta peneliti juga berkonsultasi kepada guru pamong terkait siswa yang dipilih. Adapun subjek yang digunakan dalam penelitian ini terlihat pada Tabel 2 berikut.

Tabel 2.

Subyek Penelitian

\begin{tabular}{clcccc}
\hline $\begin{array}{c}\text { Nomor } \\
\text { Urut }\end{array}$ & $\begin{array}{l}\text { Inisial } \\
\text { Nama } \\
\text { Siswa }\end{array}$ & L/P & Nilai & Kelompok & Kode \\
\hline 3 & ARNN & L & 100 & Tinggi & SB.T \\
\hline 17 & KAS & P & 80 & Sedang & SB.S \\
\hline 18 & KPT & L & 60 & Rendah & SB.R
\end{tabular}

Setelah terpilih ketiga subyek tersebut, kemudian dilakukan TBKM dan wawancara dimana kemudian data yang diperoleh dari kedua teknik tersebut direduksi dengan cara memilih data yang sesuai dengan indikator berpikir kreatif yaitu fluency, flexibility dan novelty. Setelah dilakukan reduksi data kemudian dilakukan penyajian 
data dan penarikan kesimpulan sebagaimana dijelaskan berikut.

\section{A. Kemampuan Berpikir Kreatif Siswa Berkemampuan Matematika Tinggi (SB.T)}

SB.T merupakan siswa berkemampuan matematika tinggi dianalisis ketika menyelesaikan masalah matematika pada materi Sistem Persamaan Linier Dua Variabel (SPLDV). Dimana materi SPLDV tersebut terdiri dari 2 soal uraian yang meminta siswa untuk membuat sistem persamaan linier yang lain dengan himpunan penyelesaian yang sama. Subjek SB.T memenuhi tiga indikator berpikir kreatif yaitu fluency, flexibility dan novelty.

Pada aspek fluency, berlandaskan hasil tes dan wawancara subjek SB.T bisa memberikan alternatif penyelesaian yang beragam, bernilai benar, serta memiliki himpunan penyelesaian yang sama. Dimana subjek SB.T pada soal nomor satu dapat memberikan 7 solusi penyelesaian dan pada nomor dua dapat memberikan 4 solusi penyelesaian yang berbeda-beda dan bernilai benar. Hal ini sejalan dengan pendapat Laduni (2017) bahwa siswa berkemampuan tinggi dapat memberikan dua alternatif atau kemungkinan jawaban bernilai benar serta dapat menentukan alternatif jawaban yang lain dengan memperhatikan pola yang dihasilkan dengan cara sebelumnya dan bernilai benar.

Kemudian pada aspek fleksibilitas (flexibility), berdasarkan hasil tes dan wawancara subyek SB.T bisa menyelesaikan masalah matematika dengan menggunakan cara yang berbeda-beda serta memiliki penyelesaian benar. Cara yang digunakan oleh SB.T meliputi mengalikan kedua ruas dengan bilangan yang sama, menentukan himpunan penyelesaian terlebih dahulu dan grafik. Hal ini sejalan dengan penelitian Hanurrani \& Susanah (2019) bahwa siswa berkemampuan tinggi dapat memberikan dua alternatif penyelesaian yang berbeda dan benar.

Sedangkan pada aspek kebaruan (novelty), berdasarkan hasil tes dan wawancara subyek SB.T dapat menunjukkan kebaruan melalui bilangan yang digunakan dalam menyelesaikan masalah karena pada setiap solusi yang diberikan dan cara yang digunakan tidak biasa dilakukan seperti siswa pada umumnya. Hal ini sesuai dengan data penelitian Mufidah (2014) bahwa subjek berkemampuan tinggi dapat menunjukkan sebuah pemikiran yang baru yang tidak pernah terpikirkan atau dilakukan oleh teman sebaya dan sepengetahuannya. Selain itu, hasil tersebut selaras dengan hasil penelitian yang dilakukan oleh Puspitasari, In'am, \& Syaifuddin (2018) bahwa siswa dengan kemampuan tinggi tidak memiliki kesulitan dalam memenuhi indikator fluency dan flexibility.

Berdasarkan pemaparan di atas dapat disimpulkan bahwa SB.T siswa berkemampuan matematika tinggi mempunyai kriteria berpikir kreatif 4 (sangat kreatif) dalam memecahkan masalah matematika pada materi SPLDV.

\section{B. Kemampuan Berpikir Kreatif Siswa Berkemampuan Matematika Sedang (SB.S)}

SB.S merupakan siswa berkemampuan matematika sedang dianalisis ketika menyelesaikan masalah matematika pada 
materi Sistem Persamaan Linier Dua Variabel (SPLDV). Dimana materi SPLDV tersebut terdiri dari 2 soal uraian yang meminta siswa untuk membuat sistem persamaan linier yang lain dengan himpunan penyelesaian yang sama. Subjek SB.S memenuhi dua indikator berpikir kreatif yaitu fluency serta flexibility.

Pada aspek kefasihan (fluency), berdasarkan hasil tes dan wawancara subjek SB.S dapat memberikan alternatif jawaban yang beragam, bernilai benar, serta memiliki himpunan penyelesaian yang sama. Dimana subjek SB.S pada soal nomor satu dan dua dapat memberikan 4 solusi penyelesaian yang berbeda-beda dan bernilai benar. Sejalan dengan penelitian yang dilakukan oleh Isna \& Kurniasari (2018) dan Prihatiningsih \& Ratu (2020) bahwa subyek berkemampuan sedang dapat menyelesaikan dengan memberikan tiga penyelesaian yang berbeda dan bernilai benar.

Kemudian pada aspek fleksibilitas (flexibility), berdasarkan hasil tes dan wawancara subjek SB.S dapat memecahkan masalah dengan menggunakan cara yang berbeda-beda dan memiliki penyelesaian bernilai benar. Cara yang digunakan oleh SB.S meliputi mengalikan kedua ruas dengan bilangan yang sama, dan menentukan himpunan penyelesaian terlebih dahulu. Hal tersebut sesuai dengan pendapat Laduni (2017) dan Murtafiah (2017) bahwa siswa dengan kemampuan sedang dapat menyelesaikan masalah dengan menggunakan dua cara yang berbeda-beda disetiap penyelesaiannya.

Sedangkan pada aspek kebaruan (novelty), berdasarkan hasil tes dan wawancara subjek SB.S tidak dapat menujukkan kebaruan karena tidak mampu menjelaskan dan memberikan penyelesaian yang tidak biasa dari siswa pada umumnya dan hanya dapat menyelesaikan suatu masalah berdasarkan pemahamannya. Hal ini sesuai dengan penelitian Isna \& Kurniasari (2018) bahwa siswa berkemampuan sedang tidak dapat menujukkan konsep lain yang belum diajarkan disekolah dan cara yang digunakan masih sering digunakan oleh siswa seusianya.

Berdasarkan penjelasan di atas dapat disimpulkan bahwa SB.S siswa dengan kemampuan matematika sedang mempunyai kriteria berpikir kreatif 3 (kreatif) dalam menyelesaikan masalah matematika pada materi SPLDV.

\section{Kemampuan Berpikir Kreatif Siswa Berkemampuan Matematika Rendah (SB.R)}

SB.R merupakan siswa berkemampuan matematika rendah dianalisis ketika menyelesaikan masalah matematika pada materi Sistem Persamaan Linier Dua Variabel (SPLDV). Dimana materi SPLDV tersebut terdiri dari 2 soal uraian yang meminta siswa untuk membuat sistem persamaan linier yang lain dengan himpunan penyelesaian yang sama. Subjek SB.R tidak memenuhi tiga indikator berpikir kreatif yaitu fluency, flexibility, dan novelty.

Pada aspek kefasihan (fluency), berdasarkan hasil tes dan wawancara subjek SB.R tidak dapat memberikan alternatif jawaban yang beragam, tetapi pada hasil akhir atau solusi yang diberikan tetap bernilai benar, dan memiliki 
himpunan penyelesaian sama. Dimana subjek SB.R pada soal nomor satu dan dua hanya dapat memberikan 1 solusi penyelesaian saja. Serupa dengan hasil penelitian Putri \& Ratu (2018) yang menyebutkan siswa dengan kemampuan rendah hanya bisa memberikan satu alternatif jawaban saja yang hasil akhirnya benar. Kemudian pada aspek fleksibilitas (flexibility), berdasarkan hasil tes dan wawancara subjek SB.R hanya bisa menyelesaikan masalah dengan menggunakan satu cara saja. Cara yang digunakan oleh SB.R juga yang sering dilakukan yakni menentukan himpunan penyelesaian terlebih dahulu. Cukup berbeda dengan Laduni (2017) menyatakan siswa berkemampuan matematika rendah dapat menujukkan cara penyelesaian yang hampir sama dengan cara sebelumnya, tetapi metode penyelesaian dan hasil akhir tidak menghasilkan kebenaran.

Sedangkan pada aspek kebaruan (novelty), berdasarkan hasil tes dan wawancara subjek SB.R tidak dapat memberikan kebaruan karena pada setiap penyelesaian yang dilakuakn sama seperti siswa pada umumnya. Seperti yang diutarakan Krisnawati (2012) dan Putri \& Mampouw (2018) bahwa subjek dengan kemampuan rendah tidak mempunyai strategi khusus untuk mendapatkan penyelesaian yang dihadapinya.

Berdasarkan pemaparan di atas dapat disimpulkan bahwa SB.R Siswa berkemampuan matematika rendah mempunyai tingkat berpikir kreatif 0 (tidak kreatif) dalam menyelesaikan masalah matematika pada materi SPLDV.

Berdasarkan penyajian data hasil analisis kemampuan berfikir kreatif siswa di atas diperoleh profil berfikir kreatif yang berbeda-beda yang dipengaruhi oleh kemampuan matematika siswa dimana siswa dengan kemampuan matematika tinggi menunjukkan tingkat berfikir kreatif yang tinggi pula. Sebagaimana hasil penelitian dari Anwar dkk. (2012) dimana terdapat hubungan antara kemampuan berfikir kreatif dan hasil belajar siswa. Selain itu hasil penelitian Saragih \& Napitupulu (2015) juga menyatakan bahwa kemampuan akademik siswa dapat diperkirakan dari kemampuan berfikir kreatif.

Untuk mengembangkan kemampuan berfikir kreatif siswa, guru dapat membiasakan siswa dengan pemberian masalah yang bersifat terbuka (Sumartini, 2019; Januariawan, Wijaya, Supadmini, \& Dewi, 2020). Selain itu juga dapat menggunakan pembelajaran yang berbasis teknologi dan permainan (Sanusi, Septian, \& Inayah, 2020).

Berdasarkan penyajian data hasil analisis kemampuan berfikir kreatif siswa di atas diperoleh profil berfikir kreatif yang berbeda-beda yang dipengaruhi oleh kemampuan matematika siswa dimana siswa dengan kemampuan matematika tinggi menunjukkan tingkat berfikir kreatif yang tinggi pula. Sebagaimana hasil penelitian dari Anwar dkk. (2012) dan Eftafiana, dkk. (2018), terdapat hubungan antara kemampuan berfikir kreatif dan hasil belajar siswa. Selain itu hasil penelitian Saragih \& Napitupulu (2015) dan Siskawati, Mustaji, \& Bachri (2020), menyatakan bahwa kemampuan akademik siswa dapat diperkirakan dari kemampuan berfikir kreatif. 
Untuk mengembangkan kemampuan berfikir kreatif siswa, guru dapat membiasakan siswa dengan pemberian masalah yang bersifat terbuka (Sumartini, 2019; Amalia, Fajriah, \& Sari, 2019). Selain itu juga, dapat menggunakan pembelajaran yang berbasis teknologi dan permainan (Artobatama, 2018; Sanusi, Septian, \& Inayah, 2020).

\section{Penutup}

Dari hasil analisis data dan pembahasan dapat disimpulkan bahwa kemampuan berfikir kreatif siswa ditentukan oleh kemampuan matematika siswa dimana siswa berkemampuan matematika tinggi memiliki tingkat berpikir sangat kreatif, siswa berkemampuan matematika sedang memiliki tingkat berpikir kreatif, sedangkan siswa berkemampuan matematika rendah memiliki tingkat berpikir tidak kreatif.

\section{Daftar Pustaka}

Akbayir, K. (2019). An Investigation about High School Students' Mathematics Anxiety Level According to Gender.Journal of Education and Training Studies, 7(7), 62-70.

Amala, M. A., \& Ekawati, R. (2016). Profil Proses Matematisasi Horizontal Dan Vertikal Siswa SMP Dalam Menyelesaikan Masalah Kontekstual Pecahan Ditinjau dari kemampuan Matematika. Jurnal IImiah Pendidikan Matematika, 3(5), 300-309.

Amalia, N. R., Fajriah, N., \& Sari, A. (2019). Pengaruh Pendekatan Scientific Terhadap Kemampuan Berpikir Kreatif Siswa SMP Menggunakan
Permasalahan Open-Ended. EDU-MAT: Jurnal Pendidikan Matematika, 7(2). Anwar, M., Muhammad Aness, Asma Khizar, Muhammad Naseer, \& Gulam Muhammad. (2012). Relationship of Creative Thinking with the Academic Achievements of Secondary School Students. International Interdisciplinary Journal of Education, 1(3), 1-4.

Apino, E., \& Retnawati, H. (2017, February). Developing instructional design to improve mathematical higher order thinking skills of students. In Journal of Physics: Conference Series (Vol. 812, No. 1, p. 012100). IOP Publishing.

Artobatama, I. (2018). Pembelajaran Stem

Berbasis Outbound Permainan

Tradisional. Indonesian Journal of Primary Education, 2(2), 40-47.

Ayuni, R., Firmansyah, D., Senjayawati, E., \& Maya, R. (2018). Analisis Tingkat Kemampuan Berpikir Kreatif Siswa Dalam Menyelesaikan Permasalahan Pada Materi Lingkaran. Jurnal Matematics Paedagogic, I/(2), 139148.

Dwiputri, F. A., \& Anggraeni, D. (2021). Penerapan Nilai Pancasila dalam Menumbuhkan Karakter Siswa Sekolah Dasar yang Cerdas Kreatif dan Berakhlak Mulia.Jurnal Pendidikan Tambusai, 5(1), 1267-1273.

Eftafiyana, S., Nurjanah, S. A., Armania, M., Sugandi, A. I., \& Fitriani, N. (2018). Hubungan antara kemampuan berpikir kreatif matematis dan motivasi belajar siswa SMP yang menggunakan pendekatan creative problem 
solving. Teorema: Teori dan Riset Matematika, 2(2), 85-92.

Fahrudi, R., Maharani, A., \& Fauzi, A. (2021). Pelatihan Tenaga Pendidikan di Sekolah Esa Sejahtera Pekanbaru: Sebuah Pendekatan Kualitatif. Jurnal IImiah Mandala Education, 7(2).

Faturohman, I., \& Afriansyah, E. A. (2020). Peningkatan Kemampuan Berpikir Kreatif Matematis Siswa melalui Creative Problem Solving. Mosharafa: Jurnal Pendidikan Matematika, 9(1), 107-118.

Fitriani, S., \& Yarmayani, A. (2018). Pengembangan Rubrik Berpikir Kreatif Siswa Menengah Atas dalam Menyelesaikan Masalah Matematika. Mosharafa: Jurnal Pendidikan Matematika, 7(1), 33-38.

Hanurrani, C. A., \& Susanah. (2019). Kemampuan Berpikir Kreatif Siswa Dalam Menyelesaikan Masalah Matematika Open-Ended Ditinjau Dari Kemampuan Matematika. Jurnal IImiah Pendidikan Matematika, 8(2), 7-14.

Huriyah, N. M. (2017). Proses Berpikir Kreatif Siswa SMA Dalam Memecahkan Masalah Matematika Open-Ended Ditinjau Dari Kemampuan Matematika. Jurnal IImiah Pendidikan Matematika, 2(6), 49-56.

Isna, N. N., \& Kurniasari, I. (2018). Identifikasi Tingkat Berpikir Kreatif Siswa Dalam Menyelesaikan Open Ended Problem Materi Aritmatika Sosial Smp Ditinjau Dari Kemampuan Matematika. Jurnal IImiah Pendidikan Matematika, 7(3), 607-613.

Januariawan, I. W., Wijaya, I. K. W. B., Supadmini, N. K., \& Dewi, D. N. (2020). Pengembangan Keterampilan Berpikir
Tingkat Tinggi Melalui Pendekatan Open-Ended. Cetta: Jurnal IImu Pendidikan, 3(2), 125-140.

Krisnawati, E. (2012). Kreativitas Siswa dalam Memecahkan Masalah Matematika Divergen Berdasarkan Kemampuan Matematika Siswa. Jurnal Pendidikan Matematika, 1(1), 1-8.

Laduni, M. (2017). Kreativitas Siswa SMP Dalam Menyelesaikan Masalah Matematika Terbuka Ditinjau Dari Kemampuan Matematika. Matematika Dan Pendidikan Matematika, 6(1), 5567.

Markovits, Z., \& Forgasz, H. (2017). "Mathematics is like a lion": Elementary students' beliefs about mathematics. Educational Studies in Mathematics, 96(1), 49-64.

Mufidah, I. (2014). Identifikasi Kemampuan Berpikir Kreatif Siswa Dalam Pemecahan Masalah Matematika Materi Segiempat dan Segitiga Ditinjau Dari Kemampuan Matematika Siswa Di Kelas VII SMPN 1 Driyorejo. Jurnal Ilmiah Pendidikan Matematika, 3(2), 113-119.

Mulyaningsih, T., \& Ratu, N. (2018). Analisis Kemampuan Berpikir Kreatif Siswa SMP Dalam Memecahkan Masalah Matematika Pada Materi Pola Barisan Bilangan. Jurnal IImiah Pendidikan Matematika, 3(1), 1-10.

Murtafiah, W. (2017). Profil kemampuan berpikir kreatif mahasiswa dalam mengajukan masalah persamaan diferensial. JIPM (Jurnal IImiah Pendidikan Matematika), 5(2), 73-81.

Nurhikmayati, I., \& Sunendar, A. (2020). Pengembangan Project Based Learning Berbasis Kearifan Lokal Berorientasi 
pada Kemampuan Berpikir Kreatif dan Kemandirian Belajar. Mosharafa: Jurnal Pendidikan Matematika, 9(1), 112

Parrot, M. A. S., \& Leong, K. E. (2018). Impact of Using Graphing Calculator in Problem Solving. International Electronic Journal of Mathematics Education, 13(3), 139-148.

Peraturan Menteri Pendidikan dan Kebudayaan Republik Indonesia Nomor 69 Tahun 2013 Tentang Kerangka Dasar dan Strukrur Kurikulum Menengah Kejuruan/Madrasah Aliyah Kejuruan.

Peraturan Pemerintah Nomor 17 Tahun 2010 Tentang Pengelolaan dan Penyelenggaraan Pendidikan.

Prihatiningsih, M., \& Ratu, N. (2020). Analisis Tingkat Berpikir Kreatif Siswa Ditinjau Dari Gaya Kognitif Field Dependent dan Field Independent. Jurnal Cendekia: Jurnal Pendidikan Matematika, 4(1), 353-364.

Putri, A. S., \& Mampouw, H. L. (2018). Profil berpikir reflektif siswa dalam menyelesaikan soal tipe-tipe perkalian ditinjau dari perbedaan kemampuan matematika dan gender. Math Didactic: Jurnal Pendidikan Matematika, 4(1), 34-46.

Puspitasari, L., In'am, A., \& Syaifuddin, M. (2018). Analysis of Students' Creative Thinking in Solving Arithmetic Problems. International Electronic Journal of Mathematics Education, 14(1), 49-60. https://doi.org/10.12973/iejme/3962

Putri, M. W. T., \& Ratu, N. (2018). Analisis Tingkat Berpikir Kreatif Siswa Dalam
Menyelesaikan Soal Luas Gabungan Pada Materi Bangun Datar Di SMP Negeri 8 Salatiga Kelas VII. Jurnal Pendidikan Berkarakter, 1(1), 103-109.

Rafiqoh, S. (2020). Arah Kecenderungan dan Isu Dalam Pembelajaran Matematika Sesuai Pembelajaran Abad 21 Untuk Menghadapi Revolusi Industri 4.0. Jurnal MathEducation Nusantara, 3(1), 58-73.

Rasnawati, A., Rahmawati, W., Akbar, P., \& Putra, H. D. (2019). Analisis kemampuan berfikir kreatif matematis siswa SMK pada materi sistem persamaan linier dua variabel (SPLDV) di kota Cimahi. Jurnal Cendekia: Jurnal Pendidikan Matematika, 3(1), 164-177. Sanusi, A. M., Septian, A., \& Inayah, S. (2020). Kemampuan Berpikir Kreatif Matematis dengan Menggunakan Education Game Berbantuan Android pada Barisan dan Deret. Mosharafa: Jurnal Pendidikan Matematika, 9(3), 511-520.

Saragih, S., \& Napitupulu, E. (2015). Developing Student-Centered Learning Model to Improve High Order Mathematical Thinking Ability. International Education Studies, 8(6), 104-112.

https://doi.org/10.5539/ies.v8n6p104

Sari, H. M., \& Afriansyah, E. A. (2020). Analisis Miskonsepsi Siswa SMP pada Materi Operasi Hitung Bentuk Aljabar. Mosharafa: Jurnal Pendidikan Matematika, 9(3), 439-450.

Saygılı, S. (2017). Examining the problem solving skills and the strategies used by high school students in solving nonroutine problems. E-International 
Journal of Educational Research, 8(2), 91-114.

Siskawati, G. H., Mustaji, M., \& Bachri, B. S. (2020). Pengaruh Project Based Learning Terhadap Kemampuan Berfikir Kreatif Siswa Pada Pembelajaran Online. Educate: Jurnal Teknologi Pendidikan, 5(2), 31-42.

Siswono, T. Y. E. (2018). Pembelajaran Matematika Berbasis Pengajuan dan Pemecahan Masalah. Bandung: Remaja Rosdakarya.

Sofyan, F. A. (2019). Implementasi HOTS pada kurikulum 2013. INVENTA: Jurnal Pendidikan Guru Sekolah Dasar, 3(1), 1-9.

Sugiyono. (2017). Metode Penelitian Pendidikan (Pendekatan Kuantitatif, Kualitatif dan R\&D). Bandung: Alfabeta.

Sujana, I. W. C. (2019). Fungsi dan tujuan pendidikan Indonesia. Adi Widya: Jurnal Pendidikan Dasar, 4(1), 29-39.

Sumartini, T. S. (2019). Kemampuan

Berpikir Kreatif Mahasiswa melalui Pembelajaran Mood, Understanding, Recall, Detect, Elaborate, and Review. Mosharafa: Jurnal Pendidikan Matematika, 8(1), 13-24.

Tohir, M., \& Abidin, Z. (2018, April). Students creative thinking skills in solving two-dimensional arithmetic series through research-based learning. InJournal of Physics: Conference Series (Vol. 1008, No. 1, p. 012072). IOP Publishing.

Undang-Undang Republik Indonesia Nomor 20 Tahun 2003 tentang Sistem Pendidikan Nasional.

Widodo, S. A., \& Ikhwanudin, T. (2018). Improving mathematical problem- solving skills through visual media. In Journal of Physics: Conference Series (Vol. 948, No. 1, p. 012004). IOP Publishing.

Wulandari, S. P., Sujadi, I., \& Aryuna, D. R. (2016). Profil Pemecahan Masalah SPLDV dengan Langkah Polya Ditinjau dari Kecerdasan Logis Matematis Siswa. PRISMA, Prosiding Seminar Nasional Matematika, 724-732. Retrieved from https://journal.unnes.ac.id/sju/index.p hp/prisma/article/view/21778

Zubaidah, S., Fuad, N. M., Mahanal, S., \& Suarsini, E. (2017). Improving creative thinking skills of students through differentiated science inquiry integrated with mind map. Journal of Turkish Science Education, 14(4), 7791.

\section{Riwayat Hidup Penulis \\ Masita Ulil Syahara.}

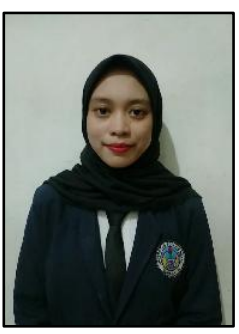

Lahir di Surabaya, 29 Juli 1997. Studi S1 Pendidikan Matematika Universitas PGRI Adi Buana Surabaya, lulus tahun 2020.

Erna Puji Astutik.

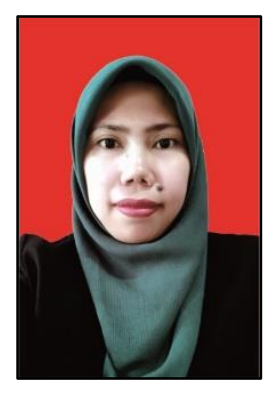

Lahir di Lamongan, 29 Agustus 1986. Dosen Program Studi S1 Pendidikan Matematika Universitas PGRI Adi Buana Surabaya. Studi S1 Matematika di Universitas Negeri Surabaya, lulus tahun 2008; S2 Dual Degree Pendidikan Matematika di Universitas Negeri Surabaya dan Science and Mathematics Education di Curtin University, Perth, lulus tahun 2013. 